\title{
Jonathan Huddleston
}

\section{Eschatology in Genesis}

[Eschatologie im Buch Genesis.]

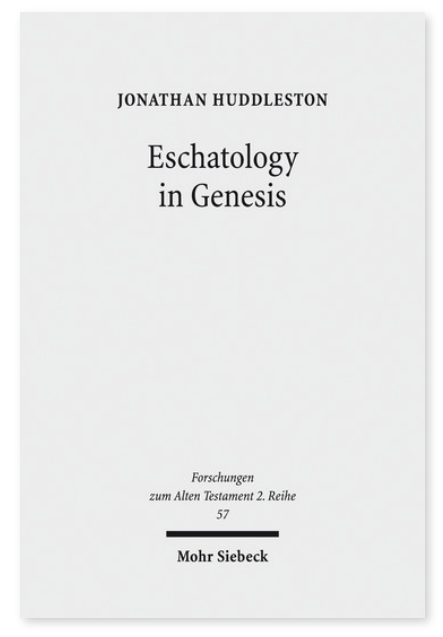

2012. XIII, 315 Seiten. FAT II 57

ISBN 978-3-16-152349-6

DOI 10.1628/978-3-16-152349-6

eBook PDF 89,00€

ISBN 978-3-16-151983-3

fadengeheftete Broschur $89,00 €$
Veröffentlicht auf Englisch.

Jonathan Huddleston untersucht das Buch Genesis als Ganzes, geht dabei jedoch vor allem auf die Erwartungen der Judäer zur Zeit des Persischen Reichs ein. Während manche die Entstehungsgeschichte in Genesis den Weissagungen durch die Propheten gegenüberstellen, deuten literarische und historische Belege darauf hin, dass das Buch Genesis die Entstehung Israels relativ genau erzählt, um einen Grundstein für die Hoffnungen Judäas auf eine eschatologische Wiederherstellung zu legen. Versprechungen an die Stammväter gelten für jene, die die Texte des Buches Genesis aufbewahrt, zusammengestellt und erhalten haben. Judäa malt sich sein mythisches Schicksal als große Nation aus, die als Vorbild dient und ihren Segen unter den Familien der Erde verbreitet. Der Weitblick des Buches Genesis im Bezug auf das Schicksal Israels hängt mit der nachexilischen prophetischen Eschatologie zusammen, die Israel als wertvollen Samen versteht, der das Versprechen einer noch nicht verwirklichten schöpferischen Fruchtbarkeit in sich trägt.

Jonathan Huddleston Born 1974; 1995 BA in Humanities and Missions; 1999 M.Div. with Honors; 2011 PhD in religion, Hebrew Bible/ Old Testament; currently Assistant Professor of Old Testament at the Graduate School of Theology, Abilene Christian University, Texas.
Jetzt bestellen:

https://mohrsiebeck.com/buch/eschatology-in-genesis-9783161523496?no_cache=1

order@mohrsiebeck.com

Telefon: +49 (0)7071-923-17

Telefax: +49 (0)7071-51104 